${ }^{[0000-0002-5179-8329]}$ О. Ю. Бондаренко, к.т.н., доцент, e-mail: julybo110976@gmail.com ${ }^{[0000-0001-9318-4301]}$ A. B. Топтун, аспірант

e-mail: anna_lapochka@bigmir.net

Черкаський державний технологічний університет б-р Шевченка, 460, м. Черкаси, 18006, Україна

\title{
РОЗРОБКА КОМПЛЕКСНОГО МЕТОДУ ВИЗНАЧЕННЯ САНІТАРНОГО СТАНУ ДЕРЕВНИХ НАСАДЖЕНЬ
}

Робота присвячена дослідженню та аналізу методів визначення санітарного стану деревних насаджень. Визначено основні вимоги до методів та засобів визначення санітарного стану деревних насаджень. Встановлено, що серед методів з найвищим рівнем інформативності є метод ультразвукової томографії. Проте такі недоліки иього методу, як висока вартість, складність в експлуатачії та необхідність обслуговування оператором високої кваліфікачіï, а також велика вага технічного оснащення не дають змоги використовувати цей метод на практиці проведення мобільного моніторингу санітарного стану дерев у польових умовах.

У роботі запропоновано якісно новий підхід до вирішення проблемного питання проведення високоефективного та оперативного визначення санітарного стану деревних насаджень иляхом розроблення нового комплексного методу, що базується на методичноматематичному й технічному забезпеченні іонометричного методу і враховує такі негативні фактори навколишнього середовища, як солоність та рН трунту, температура повітря, а також встановлення закономірностей між ичим факторами та якісними показниками деревного соку (рH, сахаристість та в'язкість). Складено алгоритм проведення високоефективного та оперативного дослідження, а також описано й проаналізовано методики визначення зовнішніх та внутрішніх показників, від яких залежить якість деревного соку та, відповідно, санітарний стан деревних насаджень.

Ключові слова: неруйнівний контроль, санітарний стан, деревні насадження, кліматичні фактори.

Актуальність. Проблема засихання та падіння дерев $\epsilon$ вкрай актуальною для сучасної інфраструктури. Інтерес до цієї проблеми зумовлений тим, що падіння дерев може призвести не лише до пошкодження та руйнування споруд промислового і побутового призначення, ліній електропередач, транспортних засобів, але й до травмування, а інколи навіть загибелі людей. Основною причиною засихання та падіння дерев $€$ внутрішні пошкодження їх крони, коріння та стовбура шкідливими комахами, а також утворення стовбурової тріщини та пустот всередині дерев.

В результаті руйнування внутрішньої структури дерево стає крихким, що впливає на його стійкість до зовнішніх збурень (пориву вітру, урагану та ін.). Останнім часом збільшилась кількість випадків падіння деревних насаджень (наприклад, в Одесі у 2020 р. ураган повалив близько двох сотень дерев) [1].

На стійкість насаджень до падіння дерев опосередковано впливає середньомісячна температура. Так, висока температура сприяє збільшенню кількості осередків розмноження шкідників. Останнім часом спостерігається збільшення температури навколишнього середовища. Така ситуація призводить до збільшення площ всихання лісових насаджень. Крім того, зростає кількість повідомлень про катастрофічне всихання лісів (в першу чергу, соснових) у багатьох регіонах України [2].

Аналіз публікацій та джерел досліджень. Постановою Кабінету Міністрів України передбачено проведення державного нагляду. Документом також виділяються шість категорій санітарного стану лісових насаджень (рисунок 1, додаток А) [3, 4].

Як показує практика, державний нагляд $\epsilon$ недосконалою системою проведення діагностики санітарного стану деревних насаджень. Використання цього методу є малоінформативним, що зумовлено аналізом лише зовнішніх ознак, тому існує необхідність проведення аналізу інших існуючих методів. 


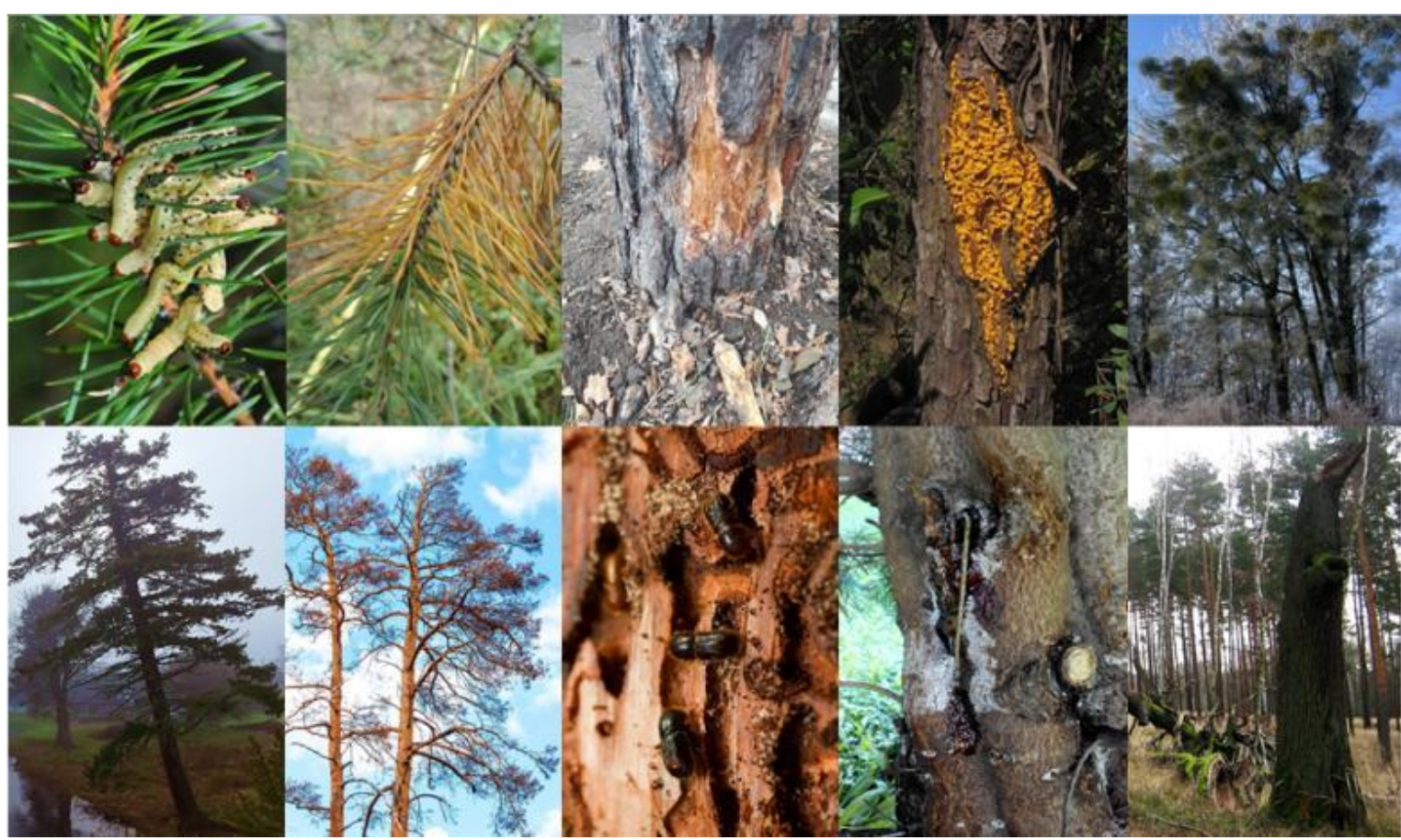

Рисунок 1 - Зовнішні ознаки неналежного санітарного стану соснових насаджень

Мета роботи - розробка комплексного методу визначення санітарного стану деревних насаджень шляхом обгрунтованого та детального аналізу існуючих методів дослідження, підвищення їх ефективності та оперативності за рахунок встановлення закономірностей між такими негативними факторами навколишнього середовища, як солоність і $p H$ грунту, температура повітря, та якісними показниками деревного соку ( $p H$, сахаристість та в'язкість).

Основна частина. Для визначення категорії санітарного стану арбористами використовуються різні методи. Загалом їх можна класифікувати на такі дві основні групи [3]:

- Візуальний метод. Визначення санітарного стану відбувається відповідно до зарегламентованого опису кожної з категорій.

- Інструментальні методи. Визначення проводиться з використанням різноманітних приладів та інформаційно-вимірювальних систем. Це зумовлено необхідністю точного оцінювання стану внутрішньої структури дерева, зокрема, надають інформацію про наявність внутрішніх тріщин, пустот та гнилей.

Візуальний метод (державний нагляд) визначення категорії стану деревних насаджень $є$ найпоширенішим. Зокрема, найчастіше його на практиці використовують державні комунальні служби.
До основних інструментальних методів визначення категорії санітарного стану (CC) відносяться наступні:

- Резистографічний метод, що визначає СС за зміною опору дерева в процесі свердління його кори.

- Бороскопічний метод, за яким робиться висновок про категорію СС в результаті аналізу отриманих зображень внутрішньої структури деревних насаджень.

- Теплометричний метод, що дає змогу проаналізувати СС дерева за швидкістю сокоруху.

- Іонометричний метод, який передбачає визначення СС за результатами аналізу зміни водневого показника $(p H)$ грунту та деревного соку.

- Метод ультразвукової томографії, що визначає дефекти в деревині за зображенням, отриманим в одній площині проходження УЗ-хвиль.

Загальні переваги та недоліки методів визначення категорій СС наведено в таблиці 1.

3 таблиці 1 випливає, що найбільш інформативним методом визначення СС деревних насаджень $є$ метод ультразвукової томографії. Проте цей метод має велику кількість недоліків: вимагає від працівників високої кваліфікації та $€$ надзвичайно складним у використанні. Важливою проблемою його використання також $€$ вага та великі розміри обладнання. 
Таблиця 1 - Переваги та недоліки методів визначення категорії санітарного стану [3-5]

\begin{tabular}{|c|c|c|c|}
\hline Метод & $\begin{array}{c}\text { Прилад, за допомогою } \\
\text { якого реалізується } \\
\text { метод } \\
\end{array}$ & Переваги & Недоліки \\
\hline $\begin{array}{l}\text { Візуальний } \\
\text { метод } \\
\text { (державний } \\
\text { нагляд) }\end{array}$ & & $\begin{array}{l}\text { - Простий у застосуванні } \\
\text { - Не потребує високої } \\
\text { кваліфікації працівників }\end{array}$ & $\begin{array}{l}\text { - Низький рівень інформа- } \\
\text { тивності } \\
\text { - Не дає інформації про } \\
\text { внутрішній стан дерев }\end{array}$ \\
\hline $\begin{array}{c}\text { Резистографіч- } \\
\text { ний метод }\end{array}$ & Резистограф & $\begin{array}{l}\text { - Середній рівень інфор- } \\
\text { мативності } \\
\text { - Дає змогу дослідити } \\
\text { внутрішню структуру } \\
\text { дерева }\end{array}$ & $\begin{array}{l}\text { - Складний у застосуванні } \\
\text { - Потребує високої кваліфі- } \\
\text { кації працівників } \\
\text { - Дорогий } \\
\text { - Аналіз в одному напрямі }\end{array}$ \\
\hline $\begin{array}{c}\text { Бороскопічний } \\
\text { метод }\end{array}$ & Бороскоп & $\begin{array}{l}\text { - Високий рівень інфор- } \\
\text { мативності } \\
\text { - С можливість дослідити } \\
\text { внутрішню структуру де- } \\
\text { рева та отримати фотозоб- } \\
\text { раження внутрішньої бу- } \\
\text { дови }\end{array}$ & $\begin{array}{l}\text { - Складний у застосуванні } \\
\text { - Потребує високої кваліфі- } \\
\text { кації працівників } \\
\text { - Дорогий } \\
\text { - Пошкоджує внутрішню } \\
\text { структуру дерева }\end{array}$ \\
\hline $\begin{array}{c}\text { Теплометрич- } \\
\text { ний метод }\end{array}$ & & $\begin{array}{l}\text { - Високий рівень інфор- } \\
\text { мативності } \\
\text { - С можливість дослідити } \\
\text { внутрішню структуру де- } \\
\text { рева та отримати фотозоб- } \\
\text { раження внутрішньої бу- } \\
\text { дови }\end{array}$ & $\begin{array}{l}\text { - Складний у застосуванні } \\
\text { - Потребує високої кваліфі- } \\
\text { кації працівників } \\
\text { - Дорогий } \\
\text { - Пошкоджує внутрішню } \\
\text { структуру дерева }\end{array}$ \\
\hline $\begin{array}{c}\text { Іонометричний } \\
\text { метод }\end{array}$ & & $\begin{array}{l}\text { - Можливість дослідити } \\
\text { зміни в фізіологічних } \\
\text { процесах дерева } \\
\text { - Не потребує високої } \\
\text { кваліфікації працівників } \\
\text { - Невисока вартість } \\
\text { - Має відносно малу вагу }\end{array}$ & $\begin{array}{l}\text { - Необхідне використання } \\
\text { кількох пристроїв одночасно } \\
\text { - Частково пошкоджує вну- } \\
\text { трішню структуру } \\
\text { - Низький рівень інформа- } \\
\text { тивності }\end{array}$ \\
\hline $\begin{array}{c}\text { Метод } \\
\text { ультразвукової } \\
\text { томографіï }\end{array}$ & & $\begin{array}{l}\text { - Високий рівень інфор- } \\
\text { мативності } \\
\text { - Можливість дослідити } \\
\text { всю внутрішню структу- } \\
\text { ру дерева в площині дос- } \\
\text { лідження } \\
\text { - Отримуємо повноцінну } \\
\text { картину СС дерева }\end{array}$ & $\begin{array}{l}\text { - Дуже складний у застосу- } \\
\text { ванні } \\
\text { - Потребує високої кваліфі- } \\
\text { кації працівників } \\
\text { - Дорогий } \\
\text { - Шкодить структурі дерева } \\
\text { - Процес дослідження є } \\
\text { досить тривалим }\end{array}$ \\
\hline
\end{tabular}

Тому найбільш перспективним для удосконалення методом вважаємо іонометричний метод. Вибір методу обгрунтований наступними перевагами перед методом ультразвукової томографії, що детально проаналізовані в таблиці 2 [5].

Проте іонометричний метод, незважаючи на наявні переваги, має один важливий недолік - відносно низький рівень інформативності. Тому в подальшому проведемо удосконалення цього методу для підвищення якості та інформативності процесу моніторингу.

(C) Ю. Ю. Бондаренко, А. В. Топтун, 2020 DOI: $10.24025 / 2306-4412.2 .2020 .198238$
Для покращення інформативності визначення СС колективом авторів проводилося розроблення нової інформаційно-вимірювальної системи. Як досліджувані параметри було обрані, зокрема, такі:

- кислотність грунту - впливає на процес засвоєння деревними насадженнями поживних речовин [6];

- солоність грунту - при збільшенні цього параметра грунт стає токсичним для більшості рослин, зокрема дерев [7];

- температура навколишнього середовища - збільшення середньомісячної темпера- 
тури призводить до утворення гнилей, збільшення осередків шкідливих комах [8] тощо;

- кислотність соку - впливає на швидкість перебігу іонообмінних процесів у деревних тканинах [9];
- сахаристість соку - впливає на процес рослинного дихання [10];

- в'язкість деревного соку - впливає на швидкість постачання поживних речовин у деревині [11].

Таблиця 2 - Порівняльний аналіз іонометричного методу та методу ультразвукової томографіï

\begin{tabular}{|c|c|c|}
\hline Перевага & Іонометричний метод & Метод ультразвукової томографії \\
\hline $\begin{array}{l}\text { Аналіз фізіо- } \\
\text { логічних про- } \\
\text { цесів дерева }\end{array}$ & $\begin{array}{l}\text { Ареал поширення соснових насаджень } \\
\text { деякою мірою залежить від зміни вод- } \\
\text { невого показника }(p H) \text { грунту. Це зумо- } \\
\text { влено відносною залежністю рівня } p H \\
\text { деревного соку від } p H \text { грунту, який } \\
\text { визначається цим методом. Це дає змо- } \\
\text { гу визначати зміни санітарного стану } \\
\text { дерева на ранніх стадіях. }\end{array}$ & $\begin{array}{l}\text { Проводить аналіз вже існуючих суттєвих } \\
\text { змін внутрішньої структури. Зокрема за } \\
\text { структурними зображеннями можна зро- } \\
\text { бити висновок щодо площі та місць роз- } \\
\text { ташування руйнувань (гнилей, пустот та } \\
\text { тріщин), але лише в межах досліджуваної } \\
\text { площини. }\end{array}$ \\
\hline $\begin{array}{l}\text { Кваліфікація } \\
\text { працівників }\end{array}$ & $\begin{array}{l}\text { Робота пристроїв на основі іонометрич- } \\
\text { ного методу є досить простою, адже } \\
\text { базується на зануренні в досліджуване } \\
\text { середовище електродів приладу та } \\
\text { фіксації їх показників. }\end{array}$ & $\begin{array}{l}\text { Робота з пристроями ультразвукової то- } \\
\text { мографії передбачає необхідність високої } \\
\text { кваліфікації обслуговуючого персоналу } \\
\text { та придбання складного спеціалізованого } \\
\text { програмного забезпечення методу. }\end{array}$ \\
\hline Вага & $\begin{array}{l}\text { Вага приладів в загальному варіюєть- } \\
\text { ся в діапазоні від } 50 \text { г до } 1 \text { кг, залежно } \\
\text { від моделі та функціональних можли- } \\
\text { востей. }\end{array}$ & $\begin{array}{l}\text { Комплектація приладу включає багато- } \\
\text { функціональні сенсори (від } 2 \text { до } \\
24 \text { штук); кейс з акумуляторним модулем } \\
\text { та іншим технічним оснащенням загаль- } \\
\text { ною вагою до } 25 \text { кг. }\end{array}$ \\
\hline Ціна & $\begin{array}{l}\text { Варіюється в діапазоні від } 300 \text { до } \\
2000 \text { грн. }\end{array}$ & $\begin{array}{l}\text { Варіюється в діапазоні від } 10 \text { до } 28 \text { тис. } \\
\text { євро. }\end{array}$ \\
\hline
\end{tabular}

В загальному випадку усі параметри можна умовно розділити на зовнішні та внутрішні. Таким чином, до зовнішніх відносяться ті, які характеризують зовнішні негативні фактори, зокрема: водневий показник $p H$ грунту, солоність, температура навколишнього середовища. До внутрішніх відносяться ті, які характеризують зміни якісних показників деревного соку, зокрема: водневий показник $p H$, сахаристість і в'язкість деревного соку.

Порівняльна характеристика зміни інформативності отриманих результатів до i після збільшення досліджуваних параметрів представлена в таблиці 3.

Таблиця 3 - Порівняльна характеристика зміни інформативності результатів дослідження до та після збільшення кількості досліджуваних параметрів

\begin{tabular}{|c|c|c|}
\hline $\begin{array}{l}\text { Оцінювані хара- } \\
\text { ктеристики про- } \\
\text { цесу вимірювань }\end{array}$ & $\begin{array}{l}\text { До збільшення кількості досліджуваних } \\
\text { параметрів (класичне вимірювання) }\end{array}$ & $\begin{array}{c}\text { Після збільшення кількості } \\
\text { досліджуваних параметрів } \\
\text { (запропонована методика) } \\
\end{array}$ \\
\hline $\begin{array}{c}\text { Рівень } \\
\text { інформативності } \\
\text { та якість визна- } \\
\text { чення СС }\end{array}$ & $\begin{array}{c}\text { Визначення категорії СС насаджень } \\
\text { відбувається лише за показниками за- } \\
\text { лежності зміни водневих показників рН } \\
\text { грунту та деревного соку, що є малоін- } \\
\text { формативним і забезпечує порівняно } \\
\text { низький рівень достовірності визначен- } \\
\text { ня правильної категорії СС }\end{array}$ & $\begin{array}{c}\text { Визначено якісні зовнішні та внутрішні } \\
\text { параметри, що впливають на СС дерев- } \\
\text { них насаджень, та виведено багатофак- } \\
\text { торну залежність між взаємодією цих } \\
\text { параметрів та їх впливом на зміну кате- } \\
\text { горії СС, що дозволяє встановлювати } \\
\text { зазначену категорію з високою точністю }\end{array}$ \\
\hline $\begin{array}{c}\text { Складність } \\
\text { вимірювання }\end{array}$ & Низький рівень складності & $\begin{array}{c}\text { Середній рівень складності } \\
\text { (підвищення складності зумовлене не- } \\
\text { обхідністю використання кількох прила- } \\
\text { дів, а саме: для вимірювання температу- } \\
\text { ри, в’язкості, солоності та сахаристості, } \\
\text { проте процедура не вимагає підвищення } \\
\text { вимог до кваліфікації дослідника) }\end{array}$ \\
\hline
\end{tabular}

(C) Ю. Ю. Бондаренко, А. В. Топтун, 2020

DOI: $10.24025 / 2306-4412.2 .2020 .198238$ 
Проведення експериментального дослідження в запропонованому авторами випадку передбачає наступну послідовність дій:

1. Обирається ділянка деревних насаджень, на якій будуть проводитися дослідження.

2. На обраній ділянці обираються дерева, які підпадають під різні категорії санітарного стану відповідно до зовнішніх ознак.

3. Кожному обраному дереву присвоюється код для ідентифікації (наприклад Д3-13, де: Д3 - досліджуваний зразок, 1 - номер по порядку, 3 - відповідна категорія СС).

4. Створюється карта розташування обраних дерев із зазначенням їх категорії.

5. Проводиться вимірювання всіх параметрів окремо для кожного дерева в один проміжок часу.
6. Проводиться вимірювання зовнішніх та внутрішніх показників.

7. Проводиться математичне оброблення отриманих результатів та отримуються залежності якісних (внутрішніх) параметрів деревного соку від негативних зовнішніх факторів.

Порядок проведення вимірювання зовнішніх та внутрішніх показників представлено в таблиці 4.

3 таблиці 4 видно, що оновлена процедура та вимірювання додаткових параметрів не $є$ складними і не вимагають від дослідника високої кваліфікації. Проте використання більшої кількості вимірювального обладнання дає можливість збільшити рівень інформативності, що, в свою чергу, приведе до підвищення якості та безпомилковості визначення категорії СС дерев.

Таблиця 4 - Порядок проведення вимірювань зовнішніх та внутрішніх показників

\begin{tabular}{|c|c|c|}
\hline Параметри & Особливості & \\
\hline$p H$ грунту & $\begin{array}{l}\text { Відстань від } \\
\text { об'єкта }-100 \text { мм } \\
\text { Глибина - } \\
100 \text { мм }\end{array}$ & $\begin{array}{l}\text { 1. Очищені сенсори занурюються на необхідну глибину. } \\
\text { 2. Очікується завершення періоду адаптації (близько } 1 \text { хв), поки } \\
\text { значення не перестануть змінюватися. } \\
\text { 3. Фіксуються результати вимірювання. }\end{array}$ \\
\hline Солоність & $\begin{array}{r}\text { Відстань } \\
\text { об'єкта - } 10\end{array}$ & $\begin{array}{l}\text { 1. На зазначеній відстані обирається зразок грунту. } \\
\text { 2. Готується водний розчин грунту у відношенні 1:1 в поперед- } \\
\text { ньо очищеній ємності, куди опускаються електроди пристрою. } \\
\text { 3. Очікується завершення періоду адаптації (близько } 1 \text { хв.), поки } \\
\text { значення не перестануть змінюватися. } \\
\text { 4. Фіксуються результати вимірювання. }\end{array}$ \\
\hline Темп & & $\begin{array}{l}\text { 1. Вмикається пристрій для вимірювання температури. } \\
\text { 2. Очікується завершення періоду адаптації (близько } 1 \text { хв.), поки } \\
\text { значення не перестануть змінюватися. } \\
\text { 3. Фіксуються результати вимірювання. }\end{array}$ \\
\hline \multicolumn{3}{|c|}{$\begin{array}{l}\text { Для визначення параметрів деревного соку: } \\
\text { 1. На висоті } 1,3 \text { м над рівнем грунтового покрову у стовбурі висвердлюється отвір глибиною до } \\
100 \text { мм. } \\
\text { 2. Збираються проби деревного соку. }\end{array}$} \\
\hline & \multicolumn{2}{|c|}{$\begin{array}{l}\text { 3.В отриману пробу занурюються електроди пристрою для вимірювання показника. } \\
\text { 4. Очікується завершення періоду адаптації (близько } 1 \text { хв.), поки значення не перес- } \\
\text { тануть змінюватися. } \\
\text { 5. Фіксуються результати вимірювання. }\end{array}$} \\
\hline В'язкість & \multicolumn{2}{|c|}{$\begin{array}{l}\text { 3. В отриману пробу занурюються електроди пристрою. } \\
\text { 4. Очікується завершення періоду адаптації (близько } 1 \text { хв.), поки значення не перес- } \\
\text { тануть змінюватися. } \\
\text { 5. Фіксуються результати вимірювання. }\end{array}$} \\
\hline Сахаристість & \multicolumn{2}{|c|}{$\begin{array}{l}\text { 3. Готується водний розчин грунту у відношенні 1:1 в попередньо очищеній ємності. } \\
\text { 4. Розчин розміщається на об'єктному столику рефлектометра, який налаштовується } \\
\text { доти, поки значення в об’єктиві не перестануть змінюватися. } \\
\text { 5. Фіксуються результати вимірювання. }\end{array}$} \\
\hline
\end{tabular}


Таким чином, за результатами проведених досліджень складено загальний алгоритм дій із визначення СС деревних насаджень (рисунок 2).

Алгоритм складається $з$ двох блоків:

I - блок налаштування інформаційновимірювальної системи моніторингу. Блок призначений для формування бази знань та правил, а також залежностей впливу негативних факторів на показники якості деревного соку. Цей блок складається 3 трьох підблоків, що передбачають три етапи дій. На першому етапі обираються негативні фактори та встановлюються діапазони їх граничних значень, на основі яких проводиться накопичення масиву даних для подальшої математичностатистичної обробки. На другому етапі, шляхом застосування методу планування експерименту (повний план), проводиться математична обробка даних, отриманих на першому етапі, в результаті чого будуть отримані рівняння регресії, що після успішної перевірки на адекватність та коректність дозволять перехід на наступний етап. На третьому етапі для більш якісного визначення категорії санітарного стану деревних насаджень застосовується метод нечіткої логіки (алгоритм Мандамі), що дає змогу скоригувати залежність вимірюваних параметрів від негативних факторів зовнішнього середовища, чим збільшує точність розрахунків на $10-15 \%$.

II - блок експериментальних досліджень. Блок застосовується для проведення польових випробувань розроблюваної системи моніторингу. До складу блоку входять три підблоки, що реалізують наступні етапи: четвертий етап - призначений для початкового збирання експериментальних даних про вплив негативних факторів на якісні показники деревного соку на обраній ділянці та подальшої математично-статистичної обробки цих даних за запропонованими на другому етапі моделями; на п'ятому етапі відбувається нейромережеве картування обраної ділянки, що дає змогу проводити візуалізацію зон розподілу окремих груп деревних масивів за категоріями санітарного стану, а також здійснювати короткочасове прогнозування (на строк 13 роки) зміни зонування санітарних ділянок деревних насаджень; на останньому - шостому - етапі розробленого алгоритму проводиться підготовка та складання узагальненого акта за результатами зроблених досліджень та моделювання, що дасть можливість прийняти рішення щодо проведення профілактичних заходів, а також санітарного вирубання дерев, які не підлягають профілактиці і лікуванню та слугують джерелами розповсюдження хвороб та шкідників.

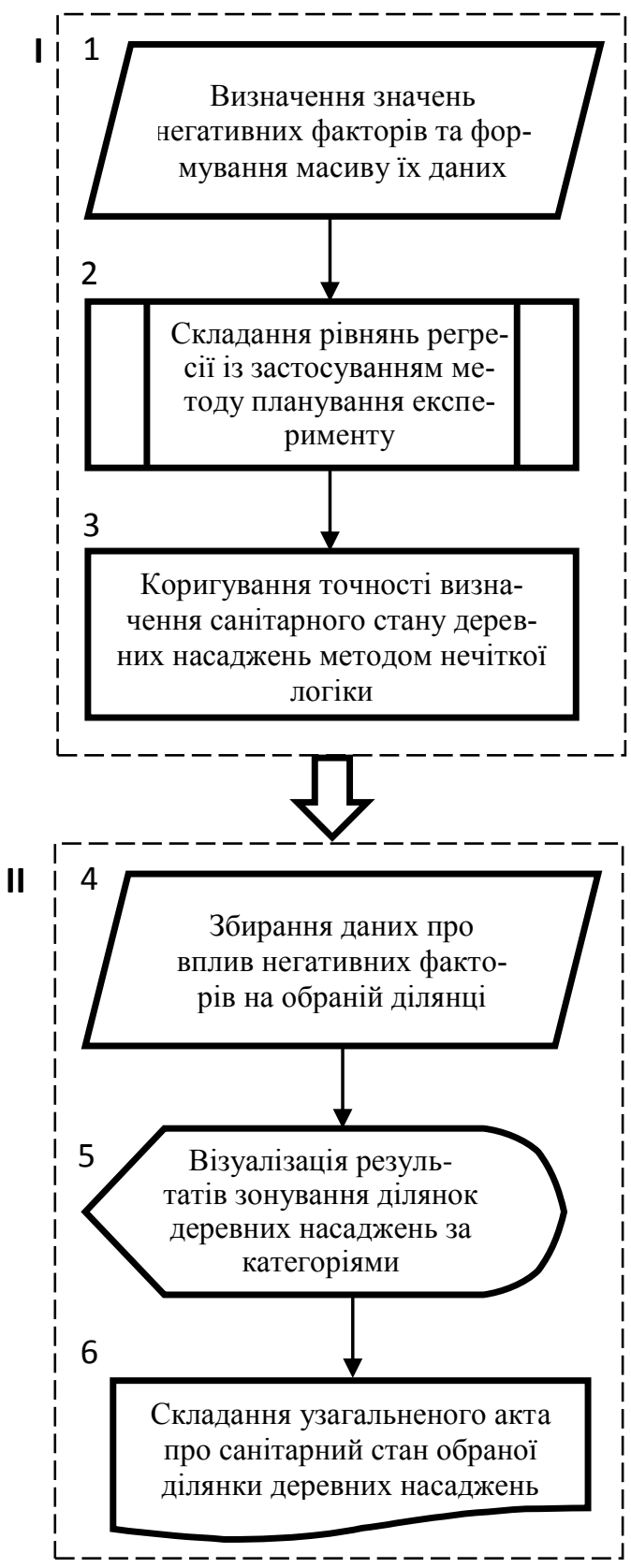

Рисунок 2 - Алгоритм розробленого в роботі методу визначення санітарного стану деревних насаджень

Висновки. В роботі проаналізовано основні методи визначення санітарного стану деревних насаджень. Серед них виділено такі найбільш застосовувані у практиці методи: візуальний, резистографічний, бороскопічний, метод ультразвукової томографії, тепломет- 
ричний та іонометричний. Визначено та порівняно переваги і недоліки цих методів.

Встановлено, що серед методів 3 найвищим рівнем інформативності є метод ультразвукової томографії. Проте такі недоліки цього методу, як висока вартість, складність в експлуатації та необхідність обслуговування оператором високої кваліфікації, а також велика вага технічного оснащення не дають змоги використовувати цей метод на практиці для проведення мобільного моніторингу санітарного стану дерев у польових умовах.

Для подальших експериментальних досліджень та застосування як базовий було обрано іонометричний метод, що вигідно відрізняється своїми дешевизною, малою вагою технічного оснащення і простотою реалізації. Проте обраний іонометричний метод потребує удосконалення через низький рівень інформативності.

В роботі запропоновано якісно новий підхід для вирішення проблемного питання проведення високоефективного та оперативного визначення санітарного стану деревних насаджень шляхом розроблення нового комплексного методу, що базується на методично-математичному і технічному забезпеченні іонометричного методу. Основними переважними відмінностями розроблюваного методу $є$ урахування таких негативних факторів навколишнього середовища, як солоність та $p H$ грунту, температура повітря, а також встановлення закономірностей між цими факторами та якісними показниками деревного соку ( $p H$, сахаристість та в'язкість).

Розроблено загальний алгоритм проведення дослідження, а також описано та проаналізовано методики визначення зовнішніх і внутрішніх показників, від яких залежить якість деревного соку та, відповідно, санітарний стан деревних насаджень.

\section{Додаток А}

\section{КАТЕГОРІЇ САНІТАРНОГО СТАНУ} ЛІСОВИХ НАСАДЖЕНЬ

I - без ознак аварійності - густа крона, хвоя зеленого кольору, швидкість річного росту відповідає сезону, віку, місцю росту, породі, віку;

II - ослаблені - середньої густоти крона; різний приріст зменшений не більше ніж на $1 / 3$; наявність незначних механічних пошкоджень (кореневих лап та стовбура); на $1 / 4$ площі стовбура напливи та рани. У пристиглих, середньовікових та молодих рослинах спостерігається об'їдання хвої на $30 \%$, та $20 \%$ - у перестиглих та стиглих деревах;

III - дуже ослаблені - крона має ажурну форму; колір хвої зелений; ріст наполовину менший за нормальний; наявні поодинокі сухі скелетні гілки в середній частині крони; на гілках спостерігаються кущі омели та нахил стовбура від вертикального до $30^{\circ}$; від $1 / 3$ до $2 / 3$ всього периметра мають механічні пошкодження; $2 / 3$ периметра стовбура вкрито раковими утвореннями; не більше ніж на $2 / 3$ злам вершини; $3 / 4$ площі обпал окоренка до стадії відмирання кадмію. Об'їдання шкідниками від 21 до $70 \%$ площі стовбура у перестійних та стиглих насаджень, у пристиглих, середньовікових та молодих - від 31 до $90 \%$;

IV - відмираючі - хвоя має жовтуватозелений або світло-зелений колір; а форма крони дуже ажурна. Річний приріст дерева повністю відсутній; відмирання більше ніж $1 / 2$ скелетних гілок по всій висоті дерева. Спостерігається ушкодження раковими утвореннями до $2 / 3$ площі стовбурів. Більше ніж до $2 / 3$ периметра механічні пошкодження стовбура або кореневих лап. Обпал кореневої шийки з відмиранням кадмію $1 / 2$ периметра або нагар стовбура, який досягає до нижньої частини крони. Більше ніж $1 / 2$ довжини всієї крони спостерігається злам верхівки або $100 \%$ обламаних живих гілок. Наявні дупла, плодові тіла або ж заселені стовбуровими шкідливими комахами (локальне відшарування кори). В деяких випадках трапляється осипання листя (дефоліація) для перестиглих, стиглих та пристиглих - понад $70 \%$, у середньовікових та молодих - понад $90 \%$. Омелою заселено більше 30 \% крони. Нахил середньої та нижньої частини стовбура дерева від вертикальної осі - понад $30^{\circ}$, а також дерева 3 дугоподібно зігнутими стовбурами;

$\mathrm{V}$ - свіжий сухостій - хвоя рудого кольору. Частково на стовбурах спостерігається опадання кори. Відпрацьовані або заселені стовбуровими шкідливими комахами. До цієї групи відносяться й дерева зі зламаними стовбурами;

VI - старий сухостій - хвоя та гілки другого та третього порядків повністю відсутні. Масове опадання кори, а під залишками кори наявна грибниця грибів, що руйнують дерево.

\section{Список використаних джерел}

[1] Рубати чи не рубати? Визначення аварійності дерев. Блог арборист. [Електронний pecypc]. Режим доступу: http://blog. arborist.com.ua/4.html Дата звернення: Черв. 21, 2018.

[2] Чому всихають соснові. Державне агентство лісових ресурсів. [Електронний ре- 
сурс]. Режим доступу: http://dklg.kmu.gov. ua/forest/control/uk/publish/article?art_id=1 95324\&cat_id=32888 Дата звернення: Лют. 29, 2020.

[3] Санітарні правила в лісах України. Постанова Кабінету Міністрів України від 27 липня 1995 р. № 555. [Електронний pecypc]. Режим доступу: https://zakon5.rada.gov.ua/laws/show/7562016-\%D0\%BF/paran11 \#n11. Дата звернення: Верес. 23, 2019.

[4] Е. А. Аносов, "Аварийные деревья зеленых насаждений городов. Методы визуальной и инструментальной диагностики аварийности, оценка состояния насаждений", Электронное научное издание «Ученые заметки ТОГУ», т. 6, № 4, c. 637-648, 2015.

[5] И. А. Мельничук, Й. М. Йассин Солиман, и О. А. Черданцева, "Диагностика внутреннего состояния деревьев tilia cordata mill, с использованием комплекса аппаратуры акустической ультразвуковой томографии «АРБОТОМ®»", Вестник РУДН. Серия: Агрономия и животноводство, № 5, с. 25-32, 2012.

[6] Кислотність грунтів та ії вплив на живлення рослин. Журнал Агроном. [Електронний ресурс]. Режим доступу: https://www.agronom.com.ua/kyslotnistgruntiv-ta-yiyi-vplyv-na-zhyv/.

[7] Влияние засоления на растения. Myzooplanet.ru. [Электронный pecypc]. Режим доступа: https://myzooplanet.ru/ rasteniya_765/vliyanie-zasoleniya-rasteniya11411.html. Дата обращения: Февр. 06, 2020.

[8] Загибель лісових насаджень за причинами (2010-2018). Держстат України, 19982019. Остання модифікація: 15.04.2019. [Електронний ресурс]. Режим доступу: http://www.ukrstat.gov.ua/operativ/operativ 2017/sg/lis/zld/zld_u/zag_lis_za_prych_u.ht m. Дата звернення: Верес. 20, 2019.

[9] "Влияние минерального питания на физико-химические свойства клеточного сока листьев артишока колючего", Научное обозрение. Биологические науки, № 3 , c. 10-13, 2017.

[10] Т. Юсипіва, та О. Борисова, "Вплив техногенного навантаження на динаміку вмісту розчинних форм вуглеводів у листках представників роду acer L.", Вісник Львівського університету. Серія біологічна, вип. 69 , с. 174-182, 2015.
[11] Цитоплазма, вязкость. Экология: справочник. Последняя модификация: 15.04.2019. [Электронный ресурс]. Режим доступа: https://ru-ecology.info/term/68190/.

\section{References}

[1] To cut or not to cut? Determination of the emergency of trees. Blog arborist. [Online]. Available: http://blog.arborist.com.ua/4.html. Accessed on: June 21, 2018.

[2] Why do pine trees dry? State Forest Resources Agency. [Online]. Available: http://dklg.kmu.gov.ua/forest/control/uk/pub lish/article?art_id=195324\&cat_id=32888 Accessed on: Febr. 29, 2020.

[3] Sanitary rules in the forests of Ukraine. Decree of the Cabinet of Ministers of Ukraine of July 27, 1995, no. 555. [Online]. Available: https://zakon5.rada.gov.ua/laws/ show/756-2016-\%D0\%BF/paran11\#n11. Accessed on: Sept. 23, 2019.

[4] E. A. Anosov, "Emergency trees of green urban areas. Methods of visual and instrumental diagnostics of emergencies, assessment of the state of plantations", Electronic scientific publication "Uchenyje zametki TOGU", vol. 6, no. 4, pp. 637-648, 2015 [in Russian].

[5] I. A. Melnichuk, Y. M. Yassin Soliman, and O. A. Cherdantseva, "Diagnostics of the internal state of tilia cordata mill trees, using the ARBOTOM ${ }^{\circledR}$ complex of acoustic ultrasound tomography equipment", Vestnik RUDN. Seriya: Agronomiya $i$ zhivotnovodstvo, no. 5, pp. 25-32, 2012 [in Russian].

[6] Soil acidity and its effect on plant nutrition. Agronom. [Online]. Available: https://www.agronom.com.ua/kyslotnistgruntiv-ta-yiyi-vplyv-na-zhyv/.

[7] The effect of salinization on plants. Myzooplanet.ru. [Online]. Available: https://myzooplanet.ru/rasteniya_765/vliyani e-zasoleniya-rasteniya-11411.html. Accessed on: Febr. 06, 2020.

[8] The loss of forest plantations by reasons (2010-2018). State Statistics Committee of Ukraine, 1998-2019. Last modified: 04/15/2019. [Online]. Available: http://www.ukrstat.gov.ua/operativ/operativ 2017/sg/lis/zld/zld_u/zag_lis_za_prych_u.ht m. Accessed on: Sept. 20, 2019.

[9] "The effect of mineral nutrition on the physico-chemical properties of the cellular juice of prickly artichoke leaves", Nauchnoe obo- 
zrenie. Biologicheskie nauki, no. 3, pp. 1013, 2017 [in Russian].

[10] T. Yusypiva, and O. Borysova, "The influence of technogenic loading on the dynamics of the content of soluble forms of carbohydrates in leaves of representatives of the genus acer L.", Visnyk Lvivskoho univer- sytetu. Seriya biologichna, iss. 69, pp. 174182, 2015 [in Ukrainian].

[11] Cytoplasm, viscosity. Ecology: a reference book. Last modification: 04/15/2019. [Online]. Available: https://ruecology.info/term/68190/.

Yu. Yu. Bondarenko, Ph. D., associate professor, e-mail: julybo110976@gmail.com

A. V. Toptun, postgraduate e-mail: anna_lapochka@bigmir.net Cherkasy State Technological University Shevchenko blvd, 460, Cherkasy, 18006, Ukraine

\section{DEVELOPMENT OF THE COMPLEX METHOD FOR DETERMINATION OF SANITARY CONDITION OF WOOD PLANTATIONS}

The work is devoted to the research and analysis of methods for determining the sanitary condition of wood plantations. Among these methods the most methods, used in practice, such as: visual, resistographic, boroscopic, ultrasonic tomography, thermometric and ionometric ones are selected. The advantages and disadvantages of these methods are identified and compared. The basic requirements to the methods and means for determining the sanitary condition of wood plantations are determined. It is established that among the methods with the highest level of information content, the method of ultrasound tomography is promising. However, such disadvantages of this method as the high cost, the complexity of operation and the need for service by high qualified operator, as well as the heavy weight of technical equipment do not allow to use this method in practice of conducting the mobile monitoring of the sanitary condition of wood plantations in the field conditions. The work proposes a qualitatively new approach to solving the problem of conducting a highly effective and efficient determination of the sanitary condition of wood plantations by developing a new integrated method based on methodological, mathematical and technical support of the ionometric method and taking into account such negative environmental factors as salinity and soil $\mathrm{pH}$, air temperature, as well as the establishment of patterns between these factors and quality indicators of wood sap (pH, sugar content and viscosity). An algorithm for conducting a highly effective and operational research is compiled, and methods for determining external and internal indicators that determine the quality of wood sap and, accordingly, the sanitary condition of tree plantations are described and analyzed.

Keywords: non-destructive control, sanitary status, tree plantations, climatic factors.

Стаття надійшла 29.01.2020

Прийнято 18.02.2020 